\title{
Penilaian Kinerja Guru Menggunakan Metode Topsis
}

\author{
Yogi Kurnia ${ }^{1}$, Arjon Samuel Sitio² Anita Sindar ${ }^{3}$ \\ ${ }^{1,2,3}$ STMIK Pelita Nusantara Medan \\ lyogikurnia87@yahoo.com, ${ }^{2}$ arjonsitio@yahoo.com, ${ }^{3}$ haito_ita@yahoo.com \\ Jl. Iskandar Muda No. 1 Medan, 20154 Indonesia
}

\begin{abstract}
Determining the level of individual contributions in completing the tasks for which they are responsible needs to be carried out objectively, transparently and through a specific method that can be trusted for accuracy. In addition to teaching in the classroom, a teacher is required to have the character as implied by Tut Wuri Handayani. The problem of the teacher performance appraisal process occurs because of unclear criteria and assessment weight. Decision Supprot System (DSS) can help the optimal decision-making process, namely TOPSIS (Technique For Order Preference by Similarity to Ideal Solution). In determining teacher performance appraisal agreed upon criteria for assessment of teacher performance assessment criteria: Pedagodic Competence (K1), Personality Competence (K2), Social Competence (K3), Proffesional Competence (K4). The acquisition of the final result of the TOPSIS calculation becomes the Teacher Performance Assessment Decision with the Status: Poor, Good, and Very Good. Very good teacher performance assessment, namely
\end{abstract}

Abstrak- Penentuan tingkat kontribusi individu dalam menyelesaian tugas-tugas yang menjadi tanggung jawabnya perlu dilakukan secara objektif, transparan dan melalui sebuah metode khusus yang dapat dipercaya keakuratannya. Selain mengajar di dalam ruang kelas, seorang guru dituntut memiliki karakter seperti yang tersirat pada Tut Wuri Handayani. Permasalahan proses penilaian kinerja guru terjadi karena ketidakjelasan kriteria dan bobot penilaian. Sebuah metode pengambil keputusan (SPK) dapat membantu proses pengambilan keputusan yang optimal yaitu TOPSIS (Technique For Order Preference by Similarity to Ideal Solution). Dalam menentukan penilaian kinerja guru disepakati kriteria penilaian Kriteria Penilaian kinerja guru: Kompetensi Pedagodik (K1), Kompetensi Kepribadian (K2), Kompetensi Sosial (K3), Kompetensi Proffesional (K4). Perolehan hasil akhir perhitungan TOPSIS menjadi Keputusan Penilaian Kinerja Guru dengan Status: Kurang Baik, Baik, dan Sangat Baik. Penilaian kinerja guru Sangat Baik yaitu Suyanto, SPd Total Nilai 0.815523 dan Rahmayuni Lubis, SPd Total Nilai $=0.75573$.

Keywords - Teacher Performance, Assessment, DSS, Topsis

\section{Pendahuluan}

Guru adalah pendidik dan pengajar yang membimbing siswa-siswi dalam mewujudkan disiplin kelas dan sebagai motivator untuk membangkitkan gairah minat siswa-siswi untuk berprestasi di kelas. Kualitas guru tidak hanya ditentukan cara mengajar di ruang kelas. Selain mengajar ada ketentuan-ketentuan yang wajib dilaksanakan setiap guru. Untuk meningkatkan kualitas guru sangat diperlukan penilaian kinerja guru secara kontinu. Penilaian kerja merupakan pengukuran organisasi terhadap tugas dan kewajiban dari setiap individu. Nilai penting dari penilaian kinerja guru adalah menyangkut penentuan tingkat kontribusi individu atau kinerja yang dilakukan dalam menyelesaikan tugas-tugas yang menjadi tanggung jawab sebagai guru [1].

Untuk mengetahui tingkat profesionalitas seorang guru, dilakukan penilaian terhadap kemampuan guru dalam melaksanakan proses pendidikan dan pengajaran. Penilain dilakukan dengan mengukur kerja masing-masing guru dalam melaksanakan tugas dan kewajibannya yang sesuai standar kompetensi yang ada. Diperlukan suatu metode dalam penilaian yang transparan dan objektif untuk menghasilkan keputusan yang adil.
Metode TOPSIS (Technique for Order Preference by Similarity o Ideal Solution) merupakan salah satu metode Sistem Pengambil Keputusan (SPK) yang akan dipergunakan dalam proses penilaian kinerja guru. Metode Topsis akan membantu kepala sekolah dalam proses evaluasi yang berhubungan dengan kinerja guru.

Sistem Pengambilan Keputusan adalah alat bantu bagi pengambilan keputusan manajerial, tetapi pengambilan keputusan memiliki beragam konteks yang berbeda [2]. Pengambilan keputusan tidak hanya memuaskan satu pihak tetapi harus bersifat memuaskan semua pihak. ). TOPSIS menggunakan prinsip bahwa alternatif yang terpilih harus mempunyai jarak terdekat dari solusi ideal positif dan jarak terpanjang dari solusi ideal negatif dari sudut pandang geometris dengan menggunakan jarak Euclidean (jarak antara dua titik) untuk menentukan kedekatan relatif dari suatu alternatif dengan solusi optimal. Pada dasarnya Topsis merupakan metode yang baik dalam pengambilan keputusan untuk mencari alternative darikriteria tertentu [3].

Beberapa peneliti yang menggunakan metode topsis: Satriawaty Mallu (2015) membahas mengenai sistem pendukung keputusan penentuan karyawan kontrak menjadi karyawan tetap 
menggunakan metode TOPSIS, Heru Purwanto (2018) pada aplikasi sistem penunjang keputusan pemilihan Notebook dengan metode TOPSIS. Dalam penelitian berjudul Sistem pendukung keputusan pemilihan guru teladan Ma Al Mubarok Batu Raja menggunakan Metode Topsis menggunakan 8 (delapan) kriteria: nilai bahasa asing, absensi, penilaian sejawat, penilaian siswa, kwalitas manager, nilai psikotest, interaksi terhadap siswa dan, sikap diluar sekolah. Dari penilaian dengan menggunakan metode TOPSIS diperoleh yang menjadi guru teladan adalah Budi Santoso S.Ag dengan nilai 0,7338 [4].

\section{Metodologi Penelitian}

A. Analisis Data

Berdasarkan Standar kompetensi guru yang dikembangkan secara utuh dari empat kompetensi utama oleh Permendiknas NOMOR 16 TAHUN 2007 tentang STANDAR KUALIFIKASI AKADEMIK DAN KOMPETENSI GURU, yaitu kompetensi pedagogik, kepribadian, sosial, dan profesional.

Kriteria kompetensi yang telah ditentukan :

1) Kompetensi Pedagodik (K1)

Kategori yang di nilai di kompetensi pedagodik:

a) Menguasai karakteristik peserta didik dari aspek fisik, moral, sosial, kultural, emosional, dan intelektual.

b) Menguasai teori belajar dan prinsip-prinsip pembelajaran yang mendidik.

c) Mengembangkan kurikulum yang terkait dengan mata pelajaran/bidang pengembangan yang diampu.

d) Menyelenggarakan pembelajaran yang mendidik.

e) Memanfaatkan teknologi informasi dan komunikasi untuk kepentingan pembelajaran.

f) Memfasilitasi pengembangan potensi peserta didik untuk mengaktualisasikan berbagai potensi yang dimiliki.

g) Berkomunikasi secara efektif, empatik, dan santun dengan peserta didik.

h) Menyelenggarakan penilaian dan evaluasi proses dan hasil belajar.

i) Memanfaatkan hasil penilaian dan evaluasi untuk kepentingan pembelajaran.

j) Melakukan tindakan reflektif untuk peningkatan kualitas pembelajaran

2) Kompetensi Kepribadian (K2)

Kategori penilaian kompetensi Kepribadian:

a) Bertindak sesuai dengan norma agama, hukum, sosial, dan kebudayaan nasional Indonesia.

b) Menampilkan diri sebagai pribadi yang jujur, berakhlak mulia, dan teladan bagi peserta didik dan masyarakat.

c) Menampilkan diri sebagai pribadi yang mantap, stabil, dewasa, arif, dan berwibawa. d) Menunjukkan etos kerja, tanggung jawab yang tinggi, rasa bangga menjadi guru, dan rasa percaya diri.

e) Menjunjung tinggi kode etik profesi guru.

3) Kompetensi Sosial (K3)

Kategori penilaian kompetensi kepribadian:

a) Bersikap inklusif, bertindak objektif, serta tidak diskriminatif karena pertimbangan jenis kelamin, agama, ras, kondisi fisik, latar belakang keluarga, dan status sosial ekonomi.

b) Berkomunikasi secara efektif, empatik, dan santun dengan sesama pendidik, tenaga kependidikan, orang tua, dan masyarakat.

c) Beradaptasi di tempat bertugas di seluruh wilayah Republik Indonesia yang memiliki keragaman sosial budaya.

d) Berkomunikasi dengan komunitas profesi sendiri dan profesi lain secara lisan dan tulisan atau bentuk lain.

4) Kompetensi Profesional (K4)

Kategori kompetensi profesional:

a) Menguasai materi, struktur, konsep, dan pola pikir keilmuan yang mendukung mata pelajaran yang diampu.

b) Menguasai standar kompetensi dan kompetensi dasar mata pelajaran/bidang pengembangan yang diampu.

c) Mengembangkan materi pembelajaran yang diampu secara kreatif.

d) Mengembangkan keprofesionalan secara berkelanjutan dengan melakukan tindakan reflektif.

e) Memanfaatkan teknologi informasi dan komunikasi untuk berkomunikasi dan mengembangkan diri.

\section{B. Perhitungan TOPSIS}

Langkah-langkah untuk penyelesaian SPK menggunakan TOPSIS:

1. Ranking tiap alternatif

TOPSIS membutuhkan rating kinerja setiap alternatif $\left(A_{i}\right)$ pada setiap kriteria $\left(C_{j}\right)$ yang ternormalisasi, yaitu :

$\boldsymbol{r}_{i j}=\frac{\boldsymbol{x}_{i j}}{\sqrt{\sum_{i=1}^{m} x_{i j}^{2}}} \mathrm{i}=1,2 . ., \mathrm{m}$ dan $\mathrm{j}=1,2, ., \mathrm{n}$

Keterangan :

$r_{i j}=$ rating kinerja ternormalisasi

$x_{i j}=$ nilai crips

$i=$ kecocokan nilai alternatif terhadap kriteria sampai ke m

$j=$ kecocokan nilai alternatif pada setiap alternatif sampai ke $n$

2. Membuat matriks keputusan ternormalisasi terbobot.

$y_{i j}=w_{i .} r_{i j}$ dengan $\mathrm{i}=1,2, ., \mathrm{m}$ dan $\mathrm{j}=1,2, . ., \mathrm{n}$

keterangan :

$y_{i j}+$ ranking bobot ternormalisasi

$w_{i}=$ nilai bobot preferensi 
3. Menentukan matriks solusi ideal positif dan matriks solusi ideal negatif. Solusi ideal positif $\left(A^{+}\right)$ dan solusi ideal negatif $\left(A^{-}\right)$dapat ditentukan berdasarkan rating bobot ternormalisasi $\left(y_{i j}\right)$ adalah sebagai berikut:

$A^{+}=\left(y_{1}{ }^{+}, y_{2}{ }^{+}, \ldots y_{n}{ }^{+}\right)$

$A^{-}=\left(y_{1}{ }^{-}, y_{2}{ }^{-}, \ldots y_{n}{ }^{-}\right)$

$A^{+}=$Solusi ideal positif $A^{-}$Solusi ideal negatif $y_{j}^{+}$adalah $=-\operatorname{Max} y_{i j}$, jika $\mathrm{j}$ adalah atribut keuntungan - Min $y_{i j}$, jika j adalah atribut biaya $y_{j}^{-}$adalah $=-$Min $y_{i j}$, jika $\mathrm{j}$ adalah atribut keuntungan - Max $y_{i j}$, jika $\mathrm{j}$ adalah atribut biaya $\mathrm{j}$ $=1,2, \ldots, \mathrm{n}$

4. Menentukan jarak antara nilai setiap alternatif $\left(A_{i}\right)$ dengan solusi ideal positif dan solusi ideal negtif.

Jarak antara alternatif $\left(A_{i}\right)$ dengan solusi ideal positif dirumuskan sebagai berikut:

$D_{i}^{+}=\sqrt{\sum_{j}^{n}\left(y_{i}^{+}-y_{i j}\right)^{2}} ; \mathrm{i} 1,2, \ldots, \mathrm{m}$

Jarak antara alternatif $\left(A_{i}\right)$ dengan solusi ideal negatif dirumuskan sebagai berikut:

$D_{i}^{+}=\sqrt{\sum_{j=i}^{n}\left(y_{i}^{-}-y_{i j}\right)^{2}} ; \mathrm{i}=1,2, \ldots, \mathrm{m}$

keterangan :

$D_{i}^{+}=$jarak antara alternatif $\left(A_{i}\right)$ solusi ideal positi

$D_{i}^{-}=$jarak antara alternatif $\left(A_{i}\right)$ solusi ideal negatif

5. Menentukan nilai preferensi untuk setiap alternatif $\left(V_{i}\right)$ dirumuskan:

$$
\begin{gathered}
V_{i}=\frac{D_{i}^{-}}{D_{i}^{-}+D_{i}^{+}} \\
\mathrm{i}=1,2, \ldots,
\end{gathered}
$$

Nilai $V_{i}$ yang lebih besar menunjukkan bahwa alternatif $A_{i}$ lebih dipilih.

C. Rancangan Implementasi Sistem

Prosedur sistem digambarkan dengan menggunakan UML (Unifield Modeling Language). Penggambaran UML menggunakan diagram use case, Gambar 1.



Gambar 1 Use Case Diagram

\section{Hasil dan Pembahasan}

\section{A. Kriteria Penilaian}

Menetukan Kriteria Penilaian

Kriteria Penilaian kinerja guru, Tabel 1: Kompetensi Pedagodik (K1), Kompetensi Kepribadian (K2), Kompetensi Sosial (K3), Kompetensi Profesional (K4).

TABEL 1

\begin{tabular}{|c|c|c|c|}
\hline No & Kriteria \& Sub Kriteria & Nilai & Keterangan \\
\hline 1 & 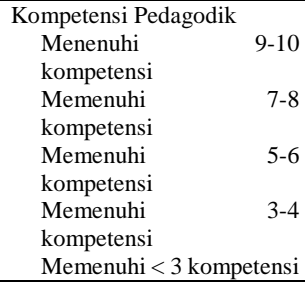 & $\begin{array}{l}1 \\
2 \\
3 \\
4 \\
5\end{array}$ & $\begin{array}{l}\text { Sangat Baik } \\
\text { Baik } \\
\text { Cukup Baik } \\
\text { Kurang Baik } \\
\text { Buruk }\end{array}$ \\
\hline 2 & $\begin{array}{l}\text { Kompetensi Kepribadian } \\
\text { Memenuhi } 1 \text { kompetensi } \\
\text { Memenuhi } 2 \text { kompetensi } \\
\text { Memenuhi } 3 \text { kompetensi } \\
\text { Memenuhi } 4 \text { kompetensi } \\
\text { Memenuhi } 5 \text { kompetensi }\end{array}$ & $\begin{array}{l}1 \\
2 \\
3 \\
4 \\
5\end{array}$ & $\begin{array}{l}\text { Buruk } \\
\text { Kurang Baik } \\
\text { Cukup Baik } \\
\text { Baik } \\
\text { Sangat Baik } \\
\end{array}$ \\
\hline 3 & $\begin{array}{l}\text { Kompetensi Sosial } \\
\text { Tidak ada } \\
\text { Memenuhi } 1 \text { kompetensi } \\
\text { Memenuhi } 2 \text { kompetensi } \\
\text { Memenuhi } 3 \text { kompetensi } \\
\text { Memenuhi } 4 \text { kompetensi }\end{array}$ & $\begin{array}{l}1 \\
2 \\
3 \\
4 \\
5\end{array}$ & $\begin{array}{l}\text { Buruk } \\
\text { Kurang Baik } \\
\text { Cukup Baik } \\
\text { Baik } \\
\text { Sangat Baik } \\
\end{array}$ \\
\hline 4 & $\begin{array}{l}\text { Kompetensi Profesional } \\
\text { Memenuhi } 1 \text { kompetensi } \\
\text { Memenuhi } 2 \text { kompetensi } \\
\text { Memenuhi } 3 \text { kompetensi } \\
\text { Memenuhi } 4 \text { kompetensi } \\
\text { Memenuhi } 5 \text { kompetensi }\end{array}$ & $\begin{array}{l}1 \\
2 \\
3 \\
4 \\
5\end{array}$ & $\begin{array}{l}\text { Buruk } \\
\text { Kurang Baik } \\
\text { Cukup Baik } \\
\text { Baik } \\
\text { Sangat Baik }\end{array}$ \\
\hline
\end{tabular}

KRITERIA PENILAIAN KINERJA GURU

Tingkat kepentingan kriteria berdasarkan nilai bobot. Skala Penilaian tersebut menggunakan Skala Linkerd:

Sangat Baik $(A)=5$,

Baik $(B)=4$,

Cukup Baik $(\mathrm{C})=3$

Kurang Baik $(\mathrm{D})=2$, Buruk $(\mathrm{E})=1$

Menentukan rating alternatif pada setiap kriteria. Nilai dari setiap kriteria yang merupakan hasil proses penginputan data ditentukan melalui proses perhitungan. Data Penilaian kinerja guru pada Tabel $2,3,4$, dan 5 .

TABEL 2

DATA PENILAIAN KOMPETENSI PEDAGODIK 1

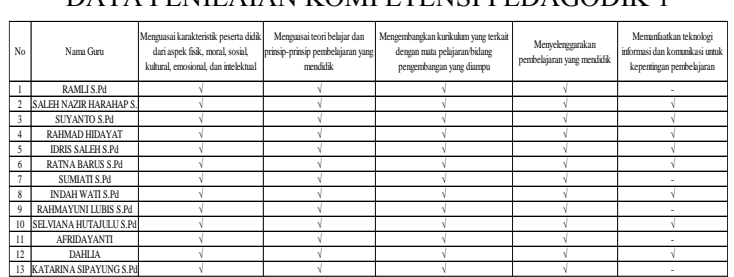


TABEL3

DATA PENILAIAN KOMPETENSI PEDAGODIK 2



TABEL 4

DATA PENILAIAN PENILAIAN KEPRIBADIAN GURU

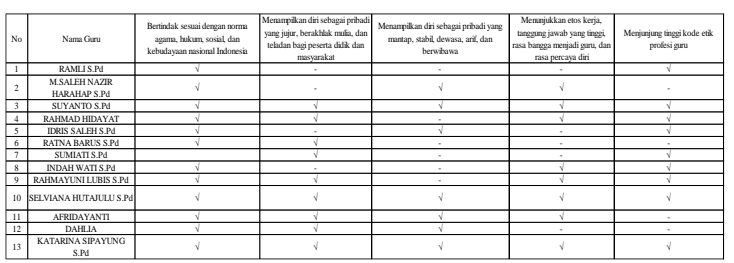

TABEL 5

DATA PENILAIAN KOMPETENSI PROFESIONAL GURU

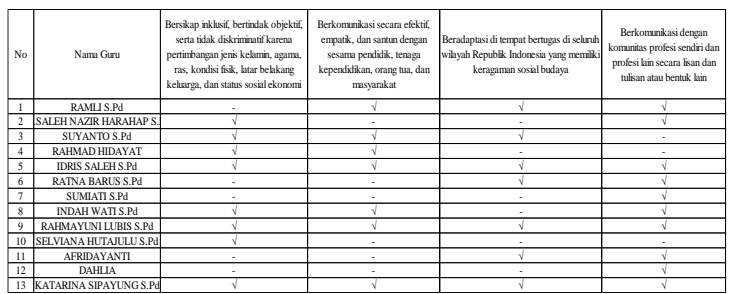

B. Implementasi TOPSIS

Berdasarkan data Tabel 2, 3, 3, 5 dibentuk peratingan dari setiap alternatif pada kriteria yang telah dikonversikan, Tabel 6:

TABEL 6

RATING KECOCOKAN

\begin{tabular}{|c|l|c|c|c|c|}
\hline \multirow{2}{*}{ Alternatif } & \multirow{2}{*}{ Nama Guru } & \multicolumn{4}{|c|}{ Kriteria (K) } \\
\cline { 3 - 6 } & & K1 & K2 & K3 & K4 \\
\hline A1 & Ramli & 1 & 2 & 4 & 4 \\
\hline A2 & M.Saleh Nazir Harahap & 1 & 3 & 3 & 4 \\
\hline A3 & Suyanto & 1 & 5 & 4 & 4 \\
\hline A4 & Rahmad Hidayat & 1 & 4 & 3 & 3 \\
\hline A5 & Idris Saleh & 1 & 3 & 5 & 4 \\
\hline A6 & Ratna Barus & 1 & 2 & 3 & 4 \\
\hline A7 & Sumiati & 1 & 2 & 2 & 4 \\
\hline A8 & Indah Wati & 1 & 3 & 4 & 4 \\
\hline A9 & Rahmayuni Lubis & 1 & 4 & 5 & 4 \\
\hline A10 & Selviana Hutajulu & 1 & 5 & 2 & 4 \\
\hline A11 & Afridayanti & 1 & 4 & 3 & 3 \\
\hline A12 & Dahlia & 1 & 3 & 2 & 3 \\
\hline A13 & Katarina Sipayung & 1 & 5 & 4 & 4 \\
\hline
\end{tabular}

Data Tabel 6 diimplementasikan dalam perhitungan Topsis:

1. Ai $=$ Alternatif Penentuan Wali Kelas.

2. $\mathrm{Cj}=$ Kriteria yang menjadi acuan dalam penentuan wali kelas terbaik.

3. Bobot preferensi untuk kriteria $C_{1}, C_{2}, C_{3}, C_{4}$ : $5,4,3,2$.

4. Berdasarkan tabel rating kecocokan, dibentuk matriks keputusan X, Tabel7:

TABEL 7

MATRIKS KEPUTUSAN X

\begin{tabular}{|c|c|c|c|c|}
\hline Alternatif & K1 & K2 & K3 & K4 \\
\hline A1 & 1 & 2 & 4 & 4 \\
\hline A2 & 1 & 3 & 3 & 4 \\
\hline
\end{tabular}

\begin{tabular}{|c|l|l|l|l|}
\hline A3 & 1 & 5 & 4 & 4 \\
\hline A4 & 1 & 4 & 3 & 3 \\
\hline A5 & 1 & 3 & 5 & 4 \\
\hline A6 & 1 & 2 & 3 & 4 \\
\hline A7 & 1 & 2 & 2 & 4 \\
\hline A8 & 1 & 3 & 4 & 4 \\
\hline A9 & 1 & 4 & 5 & 4 \\
\hline A10 & 1 & 5 & 2 & 4 \\
\hline A11 & 1 & 4 & 3 & 3 \\
\hline A12 & 1 & 3 & 2 & 3 \\
\hline A13 & 1 & 5 & 4 & 4 \\
\hline
\end{tabular}

Normalisasi Matriks Keputusan X, Tabel 8 . Persamaan 7:


dan $\mathrm{j}=1,2, \ldots ., \mathrm{n}$

TABEL 8

KRITERIA KOMPETENSI PEDAGODIK

\begin{tabular}{|c|c|c|c|c|c|c|c|}
\hline \multicolumn{2}{|c|}{ Pedagodik } & \multicolumn{2}{|c|}{ Kepribadian } & \multicolumn{2}{|c|}{ Sosial } & \multicolumn{2}{|c|}{$\begin{array}{l}\text { Profesional } \\
\end{array}$} \\
\hline $\mathrm{ra}_{1} \mathrm{k}_{1}$ & 0,2774 & $\mathrm{ra}_{1} \mathrm{k}_{3}$ & $\mathrm{ra}_{1} \mathrm{k}_{3}$ & $\mathrm{ra}_{1} \mathrm{k}_{3}$ & 0,3142 & $\mathrm{ra}_{1} \mathrm{k}_{4}$ & 0,2925 \\
\hline $\mathrm{ra}_{2} \mathrm{k}_{1}$ & 0,2774 & $\mathrm{ra}_{2} \mathrm{k}_{3}$ & $\mathrm{ra}_{2} \mathrm{k}_{3}$ & $\mathrm{ra}_{2} \mathrm{k}_{3}$ & 0,2357 & $\mathrm{ra}_{2} \mathrm{k}_{4}$ & 0,2925 \\
\hline $\mathrm{ra}_{3} \mathrm{k}_{1}$ & 0,2774 & $\mathrm{ra}_{3} \mathrm{k}_{3}$ & $\mathrm{ra}_{3} \mathrm{k}_{3}$ & $\mathrm{ra}_{3} \mathrm{k}_{3}$ & 0,3142 & $\mathrm{ra}_{3} \mathrm{k}_{4}$ & 0,2925 \\
\hline $\mathrm{ra}_{4} \mathrm{k}_{1}$ & 0,2774 & $\mathrm{ra}_{4} \mathrm{k}_{3}$ & $\mathrm{ra}_{4} \mathrm{k}_{3}$ & $\mathrm{ra}_{4} \mathrm{k}_{3}$ & 0,2357 & $\mathrm{ra}_{4} \mathrm{k}_{4}$ & 0,2193 \\
\hline $\mathrm{ra}_{5} \mathrm{k}_{1}$ & 0,2774 & rask & rask & rask & 0,3928 & $\mathrm{ra}_{5} \mathrm{k}_{4}$ & 0,2925 \\
\hline $\mathrm{ra}_{6} \mathrm{k}_{1}$ & 0,2774 & $\mathrm{ra}_{6} \mathrm{k}_{3}$ & $\mathrm{ra}_{6} \mathrm{k}_{3}$ & $\mathrm{ra}_{6} \mathrm{k}_{3}$ & 0,2357 & $\mathrm{ra}_{6} \mathrm{k}_{4}$ & 0,2925 \\
\hline $\mathrm{ra}-\mathrm{k}_{1}$ & 0,2774 & $\mathrm{ra}_{\mathrm{r}} \mathrm{k}_{3}$ & $\mathrm{ra}_{\mathrm{k}} \mathrm{k}_{3}$ & $\mathrm{ra} \mathrm{k}_{3}$ & 0,1571 & $\mathrm{ra}_{7} \mathrm{k}_{4}$ & 0,2925 \\
\hline $\mathrm{ra}_{8} \mathrm{k}_{1}$ & 0,2774 & $\mathrm{rask}_{3}$ & $\mathrm{ra}_{8} \mathrm{k}_{3}$ & $\mathrm{ras}_{\mathrm{k}} \mathrm{k}_{3}$ & 0,3142 & $\mathrm{ra}_{8} \mathrm{k}_{4}$ & 0,2925 \\
\hline rask $_{1}$ & 0,2774 & $\mathrm{ravk}_{3}$ & raok $_{3}$ & $\mathrm{ra}_{3} \mathrm{k}_{3}$ & 0,3928 & $\mathrm{ragk}_{4}$ & 0,2925 \\
\hline $\mathrm{ra}_{10} \mathrm{k}_{1}$ & 0,2774 & $\mathrm{ra}_{10} \mathrm{k}_{3}$ & $\mathrm{ra}_{10} \mathrm{k}_{3}$ & $\mathrm{ra}_{10} \mathrm{k}_{3}$ & 0,1571 & $\mathrm{ra}_{10} \mathrm{k}_{4}$ & 0,2925 \\
\hline $\mathrm{ra}_{11} \mathrm{k}_{1}$ & 0,2774 & $\mathrm{ra}_{11} \mathrm{k}_{3}$ & $\mathrm{ra}_{11} \mathrm{k}_{3}$ & $\mathrm{ra}_{11} \mathrm{k}_{3}$ & 0,2357 & $\mathrm{ra}_{11} \mathrm{k}_{4}$ & 0,2193 \\
\hline $\mathrm{ra}_{12} \mathrm{k}_{1}$ & 0,2774 & $\mathrm{ra}_{2} \mathrm{k}_{3}$ & $\mathrm{ra}_{2} \mathrm{k}_{3}$ & $\mathrm{ra}_{2} \mathrm{k}_{3}$ & 0,1571 & $\mathrm{ra}_{12} \mathrm{k}_{4}$ & 0,2193 \\
\hline $\mathrm{ra}_{13} \mathrm{k}_{1}$ & 0,2774 & $\mathrm{ra}_{13} \mathrm{k}_{3}$ & $\mathrm{ra}_{13} \mathrm{k}_{3}$ & $\mathrm{ra}_{\mathrm{I}_{3} \mathrm{k}_{3}}$ & 0,3142 & $\mathrm{ra}_{13} \mathrm{k}_{4}$ & 0,2925 \\
\hline
\end{tabular}

5. Normalisasi Matriks R, Tabel 9

TABEL 9

NORMALISASI MATRIKS R

\begin{tabular}{|c|c|c|c|c|}
\hline Alternatif & $\mathrm{K} 1$ & $\mathrm{~K} 2$ & $\mathrm{~K} 3$ & $\mathrm{~K} 4$ \\
\hline ALTR1 & 0,2774 & 0,1529 & 0,3143 & 0,2925 \\
\hline ALTR2 & 0,2774 & 0,2294 & 0,2357 & 0,2925 \\
\hline ALTR3 & 0,2774 & 0,3824 & 0,3143 & 0,2925 \\
\hline ALTR4 & 0,2774 & 0,3059 & 0,2357 & 0,2194 \\
\hline ALTR5 & 0,2774 & 0,2294 & 0,3928 & 0,2925 \\
\hline ALTR6 & 0,2774 & 0,1529 & 0,2357 & 0,2925 \\
\hline ALTR7 & 0,2774 & 0,1529 & 0,1571 & 0,2925 \\
\hline ALTR8 & 0,2774 & 0,2294 & 0,3143 & 0,2925 \\
\hline ALTR9 & 0,2774 & 0,3059 & 0,3928 & 0,2925 \\
\hline ALTR10 & 0,2774 & 0,3824 & 0,1571 & 0,2925 \\
\hline ALTR11 & 0,2774 & 0,3059 & 0,2357 & 0,2194 \\
\hline ALTR12 & 0,2774 & 0,2294 & 0,1571 & 0,2194 \\
\hline ALTR13 & 0,2774 & 0,3824 & 0,3143 & 0,2925 \\
\hline
\end{tabular}

Menentukan matriks yang ternormalisasi terbobot dengan mengkalikan bobot (w) dengan rating kinerja (r_ij) berdasarkan persamaan y_ij $=\mathrm{w}_{-} \mathrm{i}$ * r_ij yaitu didapatkan dari perkalian matriks $R$ dengan bobot preferensi W [5,4,3,2], Tabel 10.

TABEL 10

MATRIKS Y

\begin{tabular}{|c|c|c|c|c|}
\hline Alternatif & K1 & K2 & K3 & K4 \\
\hline A1 & 1,3868 & 0,6118 & 0,9428 & 0,5850 \\
\hline A2 & 1,3868 & 0,9177 & 0,7071 & 0,5850 \\
\hline A3 & 1,3868 & 1,5294 & 0,9428 & 0,5850 \\
\hline A4 & 1,3868 & 1,2236 & 0,7071 & 0,4388 \\
\hline A5 & 1,3868 & 0,9177 & 1,1785 & 0,5850 \\
\hline A6 & 1,3868 & 0,6118 & 0,7071 & 0,5850 \\
\hline A7 & 1,3868 & 0,6118 & 0,4714 & 0,5850 \\
\hline A8 & 1,3868 & 0,9177 & 0,9428 & 0,5850 \\
\hline A9 & 1,3868 & 1,2236 & 1,1785 & 0,5850 \\
\hline A10 & 1,3868 & 1,5294 & 0,4714 & 0,5850 \\
\hline A11 & 1,3868 & 1,2236 & 0,7071 & 0,4388 \\
\hline A12 & 1,3868 & 0,9177 & 0,4714 & 0,4388 \\
\hline A13 & 1,3868 & 1,5294 & 0,9428 & 0,5850 \\
\hline
\end{tabular}


Menentukan solusi ideal positif dan solusi ideal negatif berdasarkan rating bobot yang ternormalisasi y_ij dengan persamaan:

$$
\begin{aligned}
& \mathrm{A}^{\wedge}+=\left(\llbracket \mathrm{y}_{-} 1 \rrbracket^{\wedge}+, \llbracket \mathrm{y}_{-} 2 \rrbracket \wedge_{+}, \cdots \rrbracket \mathrm{y}_{-} \mathrm{n} \rrbracket{ }^{\wedge}+\right) \mathrm{dan} \mathrm{A}^{\wedge}-=\left(\llbracket \mathrm{y}_{-} 1\right.
\end{aligned}
$$

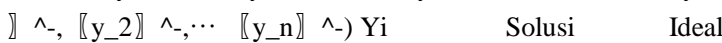

$$
\begin{aligned}
& \mathrm{Max} /+\mathrm{Min} / \text { - }
\end{aligned}
$$

Untuk mendapatkan nilai $\mathrm{A}+$ menggunakan rumus sebagai berikut:

$\mathrm{A}+=(\mathrm{y} 1+, \mathrm{y} 2+, \ldots, \mathrm{yn}+)$.

Untuk mendapatkan nilai A- menggunakan rumus sebagai berikut:

$\mathrm{A}-=(\mathrm{y} 1-, \mathrm{y} 2-, \ldots \mathrm{yn}-)$

menentukan jarak antara nilai alternatif dengan matriks solusi ideal positif dan solusi ideal negatif. Jarak antara nilai terbobot setiap alternatif terhadap solusi ideal positif sebagai berikut : 【D_i】 $\wedge_{+}=\sqrt{ }$

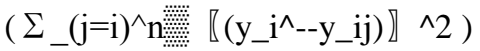

menentukan nilai preferensi untuk setiap alternatif (V_i), kedekatan setiap alternatif terhadap solusi ideal terhitung dengan persamaan:

$\mathrm{V} \_\mathrm{i}=\left(\mathrm{D} \_\mathrm{i}^{\wedge}{ }_{-}\right) /\left(\mathrm{D} \mathrm{i}^{\mathrm{i}^{\wedge}-}+\mathrm{D} \mathrm{i}^{\wedge}{ }^{\wedge}+\right)$

hasil perhitungan Topsis Tabel 12 .

TABEL 11

RENTANG NILAINYA

\begin{tabular}{|c|c|}
\hline Rentang Nilai & Status \\
\hline $0,00-0,35$ & Kurang Baik \\
\hline $0,36-0,70$ & Baik \\
\hline $0,71-1,00$ & Sangat Baik \\
\hline
\end{tabular}

TABEL 12

HASIL AKHIR PERHITUNGAN TOPSIS

\begin{tabular}{|c|l|c|c|}
\hline No & \multicolumn{1}{|c|}{ Alternatif } & Total Nilai & Status Kredit \\
\hline 1 & Ramli S.Pd & 0,34 & Kurang Baik \\
\hline 2 & M.Saleh Nazir Harahap S.Pd & 0,34 & Kurang Baik \\
\hline 3 & Suyanto S.Pd & 0,81 & Sangat Baik \\
\hline 4 & Rahmad Hidayat & 0,53 & Baik \\
\hline 5 & Idris Saleh S.Pd & 0,56 & Baik \\
\hline 6 & Ratna Barus S.Pd & 0,21 & Kurang Baik \\
\hline 7 & Sumiati S.Pd & 0,11 & Kurang Baik \\
\hline 8 & Indah Wati S.Pd & 0,46 & Baik \\
\hline 9 & Rahmayuni Lubis S.Pd & 0,75 & Sangat Baik \\
\hline 10 & Selviana Hutajulu S.Pd & 0,56 & Baik \\
\hline 11 & Afridayanti & 0,53 & Baik \\
\hline 12 & Dahlia & 0,24 & Kurang Baik \\
\hline 13 & Katarina Sipayung S.Pd & 0,81 & Sangat Baik \\
\hline
\end{tabular}

Setelah melakukan proses implementasi, proses selanjutnya adalah uji coba dengan tujuan untuk mengetahui bahwa aplikasi yang telah dibuat sesuai dengan kebutuhan. Form-form dari pengujian sistem, Tabel 13:

TABEL 13

HASIL PENGUJIAN

\begin{tabular}{|l||c|l|}
\hline \multicolumn{1}{|c|}{ Nama_Guru } & \multicolumn{1}{|c|}{ N_final } & Status \\
\hline \hline Ramli S.Pd & 0.342514994422111 & Kurang Baik \\
\hline Selviana Hutajulu S.Pd & 0.567875968731552 & Baik \\
\hline Afridayanti & 0.530307881547039 & Baik \\
\hline Dahlia & 0.244264485731827 & Kurang Baik \\
\hline
\end{tabular}

\begin{tabular}{|l|c||l|}
\hline \multicolumn{1}{|c|}{ Nama_Guru } & N_final & Status \\
\hline \hline Katarina Sipayung S.Pd & 0.815523262260108 & Sangat Baik \\
\hline M.Saleh Nazir Harahap S.Pd & 0.348389481383805 & Kurang Baik \\
\hline Suyanto S.Pd & 0.815523262260108 & Sangat Baik \\
\hline Rahmad Hidayat & 0.530307881547039 & Baik \\
\hline Idris Saleh S.Pd & 0.561755389506892 & Baik \\
\hline Ratna Barus S.Pd & 0.211902137298812 & Kurang Baik \\
\hline Sumiati S.Pd & 0.112094120645131 & Kurang Baik \\
\hline Indah Wati S.Pd & 0.469692118452961 & Baik \\
\hline Rahmayuni Lubis S.Pd & 0.755735514268173 & Sangat Baik \\
\hline \hline
\end{tabular}

\section{Implementasi Sistem}

Form Data Kriteria, berisikan data dari setiap Guru yang akan diuji, Gambar 2. Form Data Penilaian: Form ini untuk memasukkan data Penilaian untuk menentukan Kinerja Guru, Gambar 3. Form Hasil Perhitungan Gambar 4, Form laporan merupakan form untuk menampilkan data hasil proses perhitungan dimana data tersebut biasa diprint out berbentuk laporan Gambar 5.



GAMBAR 2 FORM DATA KRITERIA

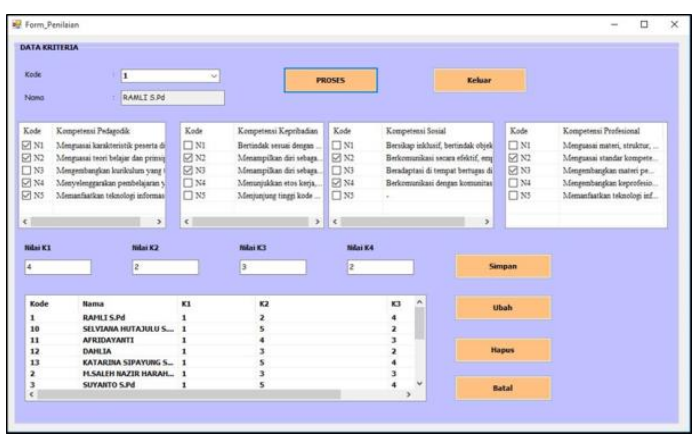

GAMBAR 3 FORM DATA PENILAIAN 


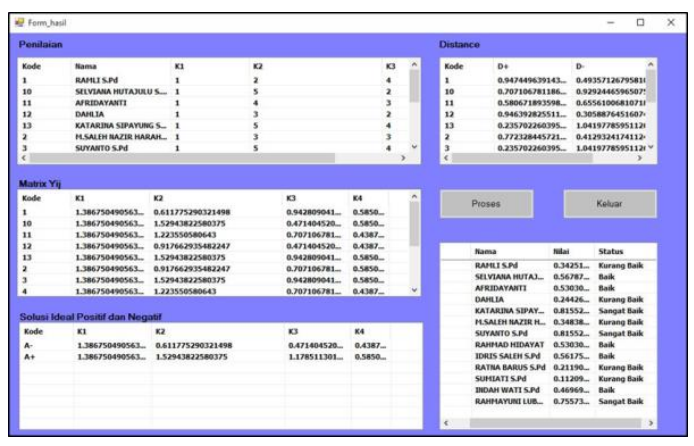

GAMBAR 4. HASIL PERHITUNGAN DENGAN TOPSIS

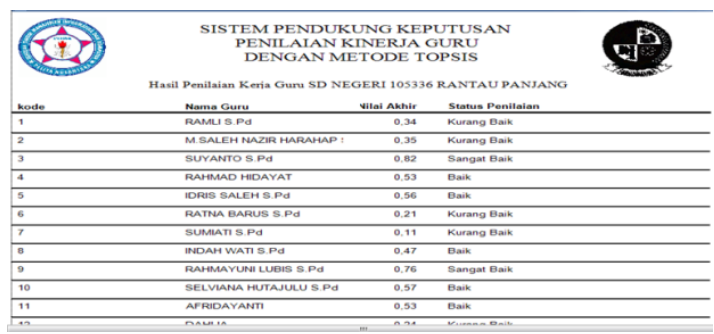

GAMBAR LAPORAN HASIL PERHITUNGAN TOPSIS

\section{KESIMPULAN}

Dalam pengujian sistem dari implementasi rancangan Penilaian Kinerja Guru dengan menginput Data Kegiatan dan Data Kriteria kemudian melakukan proses perhitungan, perolehan hasil akhir perhitungan TOPSIS menjadi Keputusan penilaian dengan Status: Kurang Baik, Baik, dan Sangat Baik. Penilaian kinerja guru Sangat Baik: Suyanto, SPd Total Nilai $=0.815523$ dan Rahmayuni Lubis, SPd Total Nilai $=0.75573$.

\section{Referensi}

[1] Hendri Ardiansyah, Sistem Penunjang Keputusan Pemilihan Guru Terbaik Dengan Metode Topsis (Technique For Order Preference By Similarity to Ideal Solution) Studi Kasus : SDN BENDUNGAN HILIR 01 Pagi Jakarta Pusat, Jurnal Informatika Universitas Pamulang 89 Vol. 2, No. 2, hal: 89-96, Juni 2017.

[2] Irvan Muzakkir, Penerapan Metode Topsis Untuk Sistem Pendukung Keputusan Penentuan Keluarga Miskin Pada Desa Panca Karsa II, ILKOM Jurnal Ilmiah Volume 9 Nomor 3 Desember 2017.

[3] Amelia Nur Fitriana, Harliana, Handaru, Sistem Pendukung Keputusan Untuk Menentukan Prestasi Akademik Siswa dengan Metode TOPSIS, Citec Journal, Vol. 2, No. 2, hal. 153-164, Februari 2015 - April 2015.

[4] Slamet Hidayat, Rita Irviani, Kasmi, Sistem Pendukung Keputusan Pemilihan Guru Teladan Ma Al Mubarok Batu Raja Menggunakan Metode Topsis, Jurnal TAM (Technology Acceptance Model) Volume 6, hal: 1-8, Juli 2016.

[5] Elyza Gustri Wahyuni, Ananto Tri Anggoro, Sistem Pendukung Keputusan Penerimaan Pegawai dengan Metode TOPSIS, Jurnal Sains, Teknologi dan Industri, Vol. 14, No. 2, pp.108 - 116, Juni 2017.

[6] Ahmad Abdul Chamid, Penerapan Metode Topsis Untuk Menentukan Prioritas Kondisi Rumah, Jurnal SIMETRIS, Vol 7 No 2 hal: 537-544 November 2016.

[7] SINAGA, Anita Sindar RM. bayes Diagnosa Penyakit Ikan Hias Air Tawar Dengan Teorema Bayes. SinkrOn, [S.1.], v. 3, n. 1, p. 43-50, Sep. 2018.
[8] Estining Nur Sejati Purnomo, Sari Widya Sihwi, Rini Anggrainingsih, URNAL ITSMART Vol 2. No 1. Juni 2013. 